\title{
INFLUENCE OF MISTLETOE (Viscum album) LEAF MEAL ON GROWTH PERFORMANCE, CARCASS CHARACTERISTICS AND BIOCHEMICAL PROFILE OF BROILER CHICKENS
}

\author{
Anthony D. Ologhobo ${ }^{1}$, Isaac Oluseun Adejumo*2, Temitope Owoeye ${ }^{1}$, Akangbe Esther $^{1}$ \\ ${ }^{1}$ University of Ibadan, Department of Animal Science, Animal Biochemistry and Nutrition Research \\ Unit, Ibadan, Nigeria \\ ${ }^{2}$ Federal University Gashua, Department of Animal Science, Animal Nutrition, Biotechnology and Food \\ Safety Laboratory, Gashua, Nigeria
}

${ }^{*}$ Corresponding author:

Phone: +2348066446246

E-mail address: smogisaac@gmail.com

\begin{abstract}
The quest for alternatives to antibiotics has resulted in the discovery of prebiotics. The search for the alterative antibiotics is on-going. Therefore, this study was carried out to investigate possible prebiotic potentials inherent in mistletoe (Viscum album) leaf meal with the aim of developing prebiotics as an alternative to antibiotics thus optimizing animal performance, carcass characteristics and a healthy blood profile as indicators of systemic conditions. Five experimental diets were formulated and mistletoe leaf meal (AMLM) was incorporated into the diets at different concentrations ( $0 \%$ with $0.05 \%$ antibiotics (positive control), $2.5 \%, 5.0 \%, 7.5 \%$ without antibiotics (negative control)). The values of body weight were not significantly different across the treatments. Live weight, bled weight, wings, drumsticks, thighs, breasts and heads were not significantly different across the treatments. Aspartate aminotransferase, globulin and creatinine contents were not significantly different across the treatments. Meanwhile, birds on AMLM-supplemented diets obtained significantly $(p<0.05)$ higher values of alanine aminotransferase than those on negative control diet $(3.75 \mathrm{lU} / \mathrm{l})$. Urea and glucose contents followed a similar pattern. The AMLM could be used as alternative antibiotics in broiler production, although further studies are required to ascertain this.
\end{abstract}

Key words: antibiotics, broiler chickens, feeding trial, Viscum album

\section{INTRODUCTION}

With the intensification of the livestock production in Nigeria, came an increase in clinical and sub-clinical enteric diseases, thus animals became vulnerable to harmful bacterial such as E. coli, Salmonella and Clostridium perfringens, resulting in reduced productivity, increased mortality and the associated contamination of meat, meat products and eggs for human consumption (EFSA BIOHAZ panel, 2013). In response to these problems, antibiotics have been used as a growth promoter
(AGP) to promote good health and enhance feed efficiency, growth and production performance in farm animals.

Antibiotics are naturally occurring, semisynthetic and synthetic compounds with anti-microbial activity that can be administered orally, parentally or topically and also be used as growth promoters at subtherapeutic levels. However, the use of antibiotics has not been without side effects. These include increase in populations of resistant pathogens and commensal bac- 
teria in the animal given antibiotics. Leaf meals have been incorporated into poultry diet for several positive reasons. The beneficial effects of leaf meals in poultry production have been reported (Egbenwade and Olorede, 2003; Murthy et al., 2006).

Leaf meals have been reported to provide antioxidants (Cross et al., 2007), antimicrobial (Manzanilla et al., 2004), immunity (Ko et al., 2008) and growth promoting effects (Lee et al., 2009). In the livestock industry, herbs and other plant extracts improve feed intake, digestibility and reinforce immunity (Wenk, 2003).

The search for the alterative antibiotics is on-going. Ologhobo et al. (2017) earlier reported that Viscum album did not have any significant on packed cell volume, haemoglobin, red blood cell counts, monocytes, eosinophils, basophils, platelets,
$\mathrm{MCV}, \mathrm{MCH}$ and $\mathrm{MCHC}$ of broiler chickens fed with diets supplemented with Viscum album. Therefore, this study was carried out to investigate possible prebiotic potentials inherent in mistletoe (Viscum album) leaf meal with the aim of developing prebiotics as an alternative to antibiotics thus optimizing animal performance, carcass characteristics and a healthy blood profile as indicators of systemic conditions.

\section{MATERIAL AND METHODS}

The study was carried out at the Poultry Unit of the Department of Animal Science, Teaching and Research Farm, University of Ibadan, Nigeria. The experimental pens were thoroughly cleaned, washed and disinfected. Fresh leaves of Viscum album from Citrus spp. (orange) trees were harvested, washed and air dried for about two weeks.

Table 1.

Gross composition of experimental diets for birds (\%) (as fed basis)

\begin{tabular}{|c|c|c|c|c|c|}
\hline $\begin{array}{l}\text { Ingredients } \\
(\%)\end{array}$ & $\begin{array}{c}\text { T}_{\text {1-positive }} \text {-pontrol } \\
\text { control } \\
\text { (0\% AMLM, } 0.05 \% \\
\text { antibiotics) }\end{array}$ & $\begin{array}{c}\mathbf{T}_{\mathbf{2}} \\
\text { (2.5\% AMLM, 0\% } \\
\text { antibiotics) }\end{array}$ & $\begin{array}{c}\mathbf{T}_{3} \\
\text { (5\% AMLM, 0\% } \\
\text { antibiotics) }\end{array}$ & $\begin{array}{c}\mathbf{T}_{4} \\
\text { (7.5\% AMLM, 0\% } \\
\text { antibiotics) }\end{array}$ & $\begin{array}{c}\mathbf{T}_{5} \text {-negative } \\
\text { control } \\
\text { (0\% AMLM, } 0 \% \\
\text { antibiotics) }\end{array}$ \\
\hline Maize & 53.30 & 53.30 & 53.30 & 53.30 & 53.30 \\
\hline Soy bean meal & 35.65 & 34.76 & 33.87 & 29.55 & 35.65 \\
\hline Fish meal & 3.00 & 3.00 & 3.00 & 3.00 & 3.00 \\
\hline Wheat offal & 2.85 & 2.85 & 2.95 & 2.95 & 2.95 \\
\hline Oyster shell & 2.00 & 2.00 & 2.00 & 2.00 & 2.00 \\
\hline $\mathrm{DCP}^{*}$ & 2.00 & 2.00 & 2.00 & 2.00 & 2.00 \\
\hline Lysine & 0.25 & 0.25 & 0.25 & 0.25 & 0.25 \\
\hline Methionine & 0.35 & 0.35 & 0.35 & 0.35 & 0.35 \\
\hline Premix & 0.35 & 0.35 & 0.35 & 0.35 & 0.35 \\
\hline Salt & 0.25 & 0.25 & 0.25 & 0.25 & 0.25 \\
\hline AMLM & 0.00 & 0.95 & 1.75 & 2.55 & 0.00 \\
\hline Antibiotics $^{\pi \pi \pi}$ & 0.05 & 0.00 & 0.00 & 0.00 & 0.00 \\
\hline \multicolumn{6}{|l|}{$\begin{array}{l}\text { Calculated } \\
\text { analysis }\end{array}$} \\
\hline Crude protein & 23.25 & 23.11 & 23.18 & 23.10 & 23.24 \\
\hline Crude fibre & 3.00 & 3.34 & 3.69 & 3.98 & 3.00 \\
\hline Ether extract & 3.65 & 3.66 & 3.64 & 3.68 & 3.66 \\
\hline Calcium & 1.45 & 1.47 & 1.49 & 1.52 & 1.45 \\
\hline Phosphorus & 0.72 & 0.74 & 0.73 & 0.75 & 0.72 \\
\hline Lysine & 0.93 & 0.93 & 0.95 & 0.97 & 0.93 \\
\hline Methionine & 0.32 & 0.34 & 0.34 & 0.35 & 0.32 \\
\hline $\mathrm{ME}(\mathrm{Kcal} / \mathrm{kg})$ & 3199.00 & 3227.00 & 3263.00 & 3279.00 & 3200.00 \\
\hline
\end{tabular}

${ }^{*}$ DCP - Dicalcium Phosphate

"Composition of Vitamin Premix per kg of diet: Vitamin A, 12500 IU; Vitamin D3, 2500 IU; Vitamin E, 40 mg; Vitamin K, $3.2 \mathrm{mg}$; Vitamin B1, $3 \mathrm{mg}$; Vitamin B2, $5.5 \mathrm{mg}$; Calcium pantothenate, $11.5 \mathrm{mg}$; Vitamin B6, $5 \mathrm{mg}$; Vitamin B12, $0.025 \mathrm{mg}$; Choline Chloride, $500 \mathrm{mg}$; Folic Acid, $1 \mathrm{mg}$; Biotin, $0.08 \mathrm{mg}$; Manganese, $120 \mathrm{mg}$; Iron, 100 mg; Zinc, 80 mg; Copper, 8.5 mg; lodine, 1.5 mg; Cobalt, 0.3 mg; Selenium, 0.12 mg; Antioxidant, 120 mg.

Antibiotics contained tetracycline hydrochloride $500 \mathrm{mg}$

AMLM - African Mistletoe Leaf Meal 
The dried leaves were separately micronized with a hammer mill into a fine powder, known as African Mistletoe Leaf Meal (AMLM), weighed and kept in sterile containers for use later.

\section{Experimental diets}

A total of five experimental diets were formulated to meet the NRC (1994) nutrient requirements for broilers. Mistletoe leaf meal (AMLM) was incorporated into the diets at different concentrations $(0 \%$, $2.5 \%, 5.0 \%$ and $7.5 \%$ ). Treatments were: $\mathrm{T}_{1}$ (standard diet $+0.05 \%$ antibiotic - positive control), $\mathrm{T}_{2}$ (standard diet $+2.5 \%$ AMLM), $\mathrm{T}_{3}$ (standard diet $+5.0 \%$ AMLM), $\mathrm{T}_{4}$ (standard diet $+7.5 \%$ AMLM) and $\mathrm{T}_{5}$ (standard diet - negative control). The gross composition of experimental diet is shown in Table 1.

\section{Determination of the chemical compo- sition of the diets}

Triplicate samples of mistletoe leaf meal (AMLM) were subjected to chemical analysis according to the method of AOAC (2000). Nitrogen free extract (NFE) was determined by difference between 100 and the sum of moisture, protein, crude fibre, fat and ash values (Table 2).

The spectrophotometric method of Akinmutimi (2006) was used for the determination of saponin, tannin, oxalate and phytates in AMLM. One gram of AMLM was dissolved in $50 \mathrm{ml}$ of butanol in a 25 $\mathrm{ml}$ beaker, the mixture was left for $5 \mathrm{~h}$ and then shaken to have a homogenous mixture. The mixture was filtered through a Whatman filter paper into a $100 \mathrm{ml}$ beaker and $20 \mathrm{ml}$ of $40 \%$ saturated solution of magnesium carbonate $\left(\mathrm{MgCO}_{3}\right)$ was added to the filtrate. The saturated solution of magnesium carbonate obtained was again filtered using Whatman filtter paper to obtain a clean colourless solution. $1 \mathrm{ml}$ of the colorless solution was pipetted into a $50 \mathrm{ml}$ volumetric flask and $2 \mathrm{ml}$ of $5 \%$ $\mathrm{FeCl}_{3}$ solution added. It was made to the mark with distilled water and allowed to stand for $30 \mathrm{~min}$. The absorbance of the solution was read on an Agilent spectrophotometer at a wavelength of $380 \mathrm{~nm}$.

Tannin was quantified by taking $2 \mathrm{~g}$ of each of AMLM in a conical flask and $10 \mathrm{ml}$ of distilled water was added. The solution was left to stand for 30 min after which 2.5 $\mathrm{ml}$ of the supernatant was taken into a 5 $\mathrm{ml}$ volumetric flask and $1 \mathrm{ml}$ of FolinDenis' reagent was added. This was followed by the addition of $2.5 \mathrm{ml}$ of saturated $\mathrm{Na}_{2} \mathrm{CO}_{3}$ and diluted to $50 \mathrm{ml}$ in a volumetric flask with distilled water. It was allowed to stay for 90 min after which the absorbance was read at $250 \mathrm{~nm}$ on a spectrophotometer.

Oxalate was determined by dissolving $2 \mathrm{~g}$ of the AMLM in $100 \mathrm{ml}$ of distilled water in a $500 \mathrm{ml}$ volumetric flask, followed by addition of $10 \mathrm{ml} 6 \mathrm{M} \mathrm{HCL}$. It was boiled for $1 \mathrm{~h}$, cooled and filtered. The content was made up to $300 \mathrm{ml}$ with distilled water. Duplicate portions of the filtrate (125 $\mathrm{ml}$ ) were taken into 5 different beakers and drops of methyl red indicator were added, followed by concentrated $\mathrm{NH}_{4} \mathrm{OH}$ solution drop wise until the test solution changed from pink to faint yellow colour.

Phytate was determined by extracting $5 \mathrm{~g}$ of AMLM with $0.2 \mathrm{~N} \mathrm{HCl} ; 0.5 \mathrm{ml}$ of the extract was pipetted into a test tube and heated in boiling water bath for $30 \mathrm{~min}$. The test tube was cooled in ice for $15 \mathrm{~min}$ and allowed to reach the room temperature. The content of the tube was mixed and centrifuged for $30 \mathrm{~min}$ at $3000 \mathrm{rpm} .1$ $\mathrm{ml}$ of the supernatant was transferred to another test tube and $1.5 \mathrm{ml}$ of $\mathrm{HCl}$ solution was added before the absorbance was read at $514 \mathrm{~nm}$ in a spectrophotometer. All determinations were carried out in triplicates.

\section{Management of experimental animals}

A total of two hundred unsexed day-old Cobb broiler chicks were used for the study. They were weighed for their initial weights and randomly allotted into five dietary treatments with forty (40) chicks per treatment. Each group had five replicates with eight (8) chicks per replicate in a completely randomized design (CRD). The birds were placed on conventional feeds for the first week after which they were randomly assigned to dietary treatments. The brooding pens were thoroughly cleaned, disinfected and allowed to rest for a period of two weeks before the arrival of the chicks. During this period, the 
pens were sealed up with polythene bags and fumigated in preparation for brooding, feeders and drinkers with other brooding materials were thoroughly washed and disinfected. Wood shavings used as litter materials were spread on the floor of the pen and a warm temperature was maintained within the pen with 100 watt electric bulbs before the arrival of the chicks. On arrival, the chicks were carefully unboxed, weighed and brooded for a period of one week before they were randomly allotted into treatments.

Fresh cool water and feed were provided adlibitum to the birds throughout the period of the experiment and routine medication (vaccination and drugs) were administered at appropriate times to birds on the positive control only.

\section{Data collection and analyses}

Feed consumption for each animal was measured daily as the difference between the daily feed supplied and refusal, and live-weight changes of the animals were taken weekly throughout the experimental period.

\section{Carcass characteristics}

The carcass characteristics were determined at the end of the experiment by selecting randomly, three birds from each replicate. The selected birds were starved of feed and water over night. Before slaughtering, the individual weight of the birds was recorded. Thereafter, the birds were slaughtered by cutting the jugular vein around the neck. The birds were immediately scalded in warm water and the feathers were manually removed. Thereafter, the fully dressed weights of the carcasses were taken and recorded. The carcasses were then separated into breast, back, upper back, thigh, shank, neck, arm, wing, drumstick, head and the internal organs (viscera). The parts were individually weighed and the weights were expressed as percentage of the live weight of the carcass. In addition, the length of the intestine of each carcass was taken and recorded. The dressing percentage and percentage weight of body in relation to the live weights of the birds were calculated by this formula:
Relative weight $=\frac{\text { Weight }}{\text { Live weight }} \times 100$

\section{Haematological parameters}

At the end of the feeding trial, blood samples were collected from the jugular vein of animals from each group into two sets of Monoject ${ }^{\circledR}$ vacutainers. One set containing ethylenediaminetetraacetic acid vacutainers (EDTA) for haematology, while the other set without EDTA was covered and centrifuged, the serum de-canted and deep-frozen for serum biochemical and enzymological analyses.

\section{Statistical analysis}

Data obtained from the experiment were subjected to analysis of variance (ANOVA) (SPSS 17.0). The variations in means were separated using the Duncan's Multiple Range Test (Duncan, 1995).

\section{RESULTS AND DISCUSSION}

The result of the proximate composition of the tested ingredient (African mistletoe leaf meal) is shown in Table 2. The leaf was rich in phytates $(22.75 \%)$ and oxalates $(15.80 \%)$ while the proximate composition of the feed samples is shown in Table 3.

The growth performance, carcass characteristics, organ weights and serum biochemical profile of broiler chickens fed with AMLM are presented in Tables 4, 5, 6 and 7 respectively. The values of body weight were not significantly different across the treatments. Feed intake was not significant during weeks 4 and 5 , while on positive control $\left(T_{1}\right)$ had the highest feed intake during the second week closely followed by those on negative control $\left(T_{5}\right)$. The feed conversion ratios (FCR) were statistically similar across the treatment during weeks 2 and 5 , while the values were not significant during weeks 3 and 4 . Birds on control diets had the highest rate of mortality when compared with those on $5.00 \%$ and $7.50 \%$ AMLM supplemented diets. Live weight, bled weight, wings, drumsticks, thighs, breasts and heads were not significantly different across the treatments. Birds on $7.50 \%$ AMLM-supplemented diet $(930.00 \mathrm{~g})$ obtained higher defeathered weights than those on positive control $(834.80 \mathrm{~g})$. 
Table 2.

Chemical composition of African mistletoe leaf meal (AMLM)

\begin{tabular}{lc}
\hline Parameters & Proportion (\%) \\
\hline Moisture content & 7.70 \\
Crude protein $^{*}$ & 3.50 \\
Ash" & 11.21 \\
Ether extracte & 7.11 \\
Crude fibre $^{*}$ & 8.90 \\
Saponins & 3.25 \\
Tannins $^{*}$ & 9.90 \\
Oxalate $^{*}$ & 15.80 \\
Oxalate & 22.75 \\
\hline "Determined on dry matter basis
\end{tabular}

Determined on dry matter basis

Table 3.

Proximate composition of feed samples

\begin{tabular}{lccccc}
\hline $\begin{array}{l}\text { Samples } \\
\text { (\%) }\end{array}$ & $\begin{array}{c}\mathbf{T}_{\text {1-positive }} \\
\text { control } \\
\text { (0\% AMLM, 0.05\% } \\
\text { antibiotics) }\end{array}$ & $\begin{array}{c}\text { (2.5\% AMLM, 0\% } \\
\text { antibiotics) }\end{array}$ & $\begin{array}{c}\mathbf{T}_{\mathbf{2}} \\
\text { (5\% AMLM, 0\% } \\
\text { antibiotics) }\end{array}$ & $\begin{array}{c}\mathbf{T}_{3} \\
(7.5 \% \text { AMLM, 0\% } \\
\text { antibiotics) }\end{array}$ & $\begin{array}{c}\mathbf{T}_{\mathbf{5}} \text {-negative } \\
\text { control } \\
\text { (0\% AMLM, 0\% } \\
\text { antibiotics) }\end{array}$ \\
\hline Dry matter & 92.10 & 92.18 & 92.49 & 92.27 & 92.40 \\
Crude protein & 23.00 & 23.50 & 23.13 & 22.77 & 24.10 \\
Crude fibre & 10.0 & 9.96 & 9.61 & 9.01 & 9.40 \\
Ether extract & 7.12 & 6.90 & 7.02 & 6.80 & 7.00 \\
Ash & 10.89 & 11.30 & 11.50 & 11.30 & 12.00 \\
\hline
\end{tabular}

AMLM - African mistletoe leaf meal

Table 4.

Growth performance of broiler chickens fed with graded levels of mistletoe leaf meal

\begin{tabular}{|c|c|c|c|c|c|c|}
\hline Parameters & $\begin{array}{c}\text { T1-positive } \\
\text { control } \\
\text { (0\% AMLM, } \\
0.05 \% \\
\text { antibiotics) }\end{array}$ & $\begin{array}{c}\mathbf{T}_{\mathbf{2}} \\
(2.5 \% \\
\text { AMLM, } \% \\
\text { antibiotics) }\end{array}$ & $\begin{array}{c}\mathbf{T}_{3} \\
\text { (5\% AMLM, } \\
0 \% \\
\text { antibiotics) }\end{array}$ & $\begin{array}{c}\mathbf{T}_{\mathbf{4}} \\
(7.5 \% \\
\text { AMLM, 0\% } \\
\text { antibiotics) }\end{array}$ & $\begin{array}{c}\text { T5 }_{5} \text {-negative } \\
\text { control } \\
(0 \% \text { AMLM, } \\
0 \% \\
\text { antibiotics) }\end{array}$ & SEM \\
\hline \multicolumn{7}{|c|}{$\begin{array}{l}\text { Body weight } \\
\text { gain (g/bird) }\end{array}$} \\
\hline Week 2 & $2.67^{\mathrm{ns}}$ & $2.25^{\mathrm{ns}}$ & $2.25^{\mathrm{ns}}$ & $2.74^{\mathrm{ns}}$ & $2.68^{\mathrm{ns}}$ & 0.96 \\
\hline Week 3 & $3.57^{\text {ns }}$ & $2.68^{\mathrm{ns}}$ & $2.98^{\text {ns }}$ & $2.36^{\text {ns }}$ & $3.08^{\mathrm{ns}}$ & 4.33 \\
\hline Week 4 & $6.63^{\text {ns }}$ & $7.14^{\text {ns }}$ & $7.36^{\text {ns }}$ & $8.05^{\mathrm{ns}}$ & $9.05^{\mathrm{ns}}$ & 0.63 \\
\hline Week 5 & $2.21^{\mathrm{ns}}$ & $2.43^{\mathrm{ns}}$ & $1.96^{\text {ns }}$ & $3.07^{\text {ns }}$ & $2.69^{\mathrm{ns}}$ & 4.10 \\
\hline \multicolumn{7}{|c|}{$\begin{array}{l}\text { Feed intake } \\
\text { (g/bird) }\end{array}$} \\
\hline Week 2 & $59.64^{a}$ & $52.14^{c}$ & $54.54^{\mathrm{cd}}$ & $51.61^{c}$ & $54.54^{\mathrm{ab}}$ & 0.85 \\
\hline Week 3 & $111.00^{\mathrm{bc}}$ & $111.61^{\mathrm{bc}}$ & $104.82^{b}$ & $118.75^{\mathrm{bc}}$ & $123.21^{a}$ & 2.47 \\
\hline Week 4 & $118.39^{\text {ns }}$ & $117.50^{\text {ns }}$ & $116.43^{\text {ns }}$ & $128.87^{\mathrm{ns}}$ & $138.71^{\mathrm{ns}}$ & 3.76 \\
\hline Week 5 & $117.11^{\mathrm{ns}}$ & $117.14^{\mathrm{ns}}$ & $114.12^{\mathrm{ns}}$ & $137.02^{\mathrm{ns}}$ & $140.21^{\mathrm{ns}}$ & 4.40 \\
\hline \multicolumn{7}{|l|}{ FCR } \\
\hline Week 2 & $22.63^{\mathrm{ab}}$ & $20.21^{\mathrm{ab}}$ & $26.33^{a}$ & $18.91^{b}$ & $21.32^{\mathrm{ab}}$ & 0.08 \\
\hline Week 3 & $31.54^{\mathrm{ns}}$ & $43.22^{\text {ns }}$ & $46.52^{\text {ns }}$ & $60.65^{\text {ns }}$ & $42.16^{\mathrm{ns}}$ & 0.19 \\
\hline Week 4 & $19.01^{\mathrm{ns}}$ & $16.78^{\mathrm{ns}}$ & $15.37^{\text {ns }}$ & $16.49^{\text {ns }}$ & $15.37^{\text {ns }}$ & 0.35 \\
\hline Week 5 & $46.99^{\mathrm{ab}}$ & $38.63^{b}$ & $67.83^{\mathrm{a}}$ & $47.52^{\mathrm{ab}}$ & $59.50^{\mathrm{ab}}$ & 0.25 \\
\hline Mortality (\%) & $1.80^{\mathrm{ab}}$ & $0.40^{\mathrm{bc}}$ & $0.20^{c}$ & $0.20^{c}$ & $2.80^{a}$ & 0.30 \\
\hline
\end{tabular}

$a, b, \ldots$ Means with different superscripts in the same row differ significantly $(p<0.05)$ different, $n s=$ non-significant, SEM = Standard Error of Mean

AMLM - African mistletoe leaf meal

Dressed weight followed a similar trend. The mean values of whole gizzard were not significantly different across the treatments. However, weights of hearts, empty gizzards and lungs were statistically simi- lar to those of the control diets. Aspartate aminotransferase, globulin and creatinine contents were not significantly different across the treatments. 
Table 5.

Carcass characteristics of broiler chickens fed with graded levels of mistletoe leaf meal

\begin{tabular}{|c|c|c|c|c|c|c|}
\hline Parameters (g) & $\begin{array}{c}\mathbf{T}_{1} \text {-positive } \\
\text { control } \\
\text { (0\% AMLM, } \\
0.05 \% \\
\text { antibiotics) }\end{array}$ & $\begin{array}{c}\mathbf{T}_{2} \\
(2.5 \% \\
\text { AMLM, } 0 \% \\
\text { antibiotics) }\end{array}$ & $\begin{array}{c}\mathbf{T}_{3} \\
\text { (5\% AMLM, } \\
0 \% \\
\text { antibiotics) }\end{array}$ & $\begin{array}{c}\mathbf{T}_{4} \\
(7.5 \% \\
\text { AMLM, } 0 \% \\
\text { antibiotics) }\end{array}$ & $\begin{array}{c}\mathbf{T}_{5} \text {-negative } \\
\text { control } \\
(0 \% \text { AMLM, } \\
0 \% \\
\text { antibiotics) }\end{array}$ & SEM \\
\hline Live weight & $954.00^{\text {ns }}$ & $936.00^{\text {ns }}$ & $960.00^{\text {ns }}$ & $1030.00^{\text {ns }}$ & $900.00^{\text {ns }}$ & 19.12 \\
\hline Bled weight & $867.20^{\text {ns }}$ & $913.60^{\text {ns }}$ & $908.20^{\text {ns }}$ & $962.00^{\text {ns }}$ & $879.00^{\text {ns }}$ & 14.86 \\
\hline Defeathered weight & t $834.80^{c}$ & $847.00^{\mathrm{bc}}$ & $865.00^{\mathrm{abc}}$ & $930.00^{a}$ & $914.80^{\mathrm{ab}}$ & 12.33 \\
\hline Dressed weight & $631.60^{\mathrm{b}}$ & $657.00^{\mathrm{ab}}$ & $633.00^{\mathrm{b}}$ & $722.00^{\mathrm{a}}$ & $666.00^{\mathrm{ab}}$ & 11.32 \\
\hline Wings & $75.56^{\text {ns }}$ & $71.00^{\text {ns }}$ & $78.20^{\text {ns }}$ & $82.54^{\text {ns }}$ & $77.84^{\text {ns }}$ & 3.24 \\
\hline Drumstick & $76.98^{\text {ns }}$ & $85.00^{\text {ns }}$ & $77.70^{\text {ns }}$ & $74.00^{\text {ns }}$ & $83.44^{\mathrm{ns}}$ & 1.87 \\
\hline Thigh & $88.00^{\text {ns }}$ & $88.80^{\text {ns }}$ & $92.98^{\text {ns }}$ & $95.42^{\text {ns }}$ & $94.84^{\mathrm{ns}}$ & 1.85 \\
\hline Breast & $156.54^{\mathrm{ns}}$ & $173.70^{\text {ns }}$ & $125.46^{\mathrm{ns}}$ & $164.78^{\text {ns }}$ & $147.04^{\mathrm{ns}}$ & 4.00 \\
\hline Back & $102.08^{\mathrm{b}}$ & $125.46^{\mathrm{a}}$ & $108.26^{\mathrm{b}}$ & $126.32^{\mathrm{b}}$ & $105.760^{\mathrm{a}}$ & 3.12 \\
\hline Neck & $40.54^{\mathrm{abc}}$ & $38.28^{\mathrm{bc}}$ & $36.00^{c}$ & $47.00^{\mathrm{a}}$ & $44.00^{\mathrm{ab}}$ & 1.18 \\
\hline Shank & $37.74^{\mathrm{ab}}$ & $35.90^{\mathrm{b}}$ & $63.64^{\mathrm{a}}$ & $46.32^{\mathrm{ab}}$ & $41.10^{\mathrm{ab}}$ & 3.93 \\
\hline Head & $27.54^{\mathrm{ns}}$ & $28.84^{\mathrm{ns}}$ & $28.50^{\text {ns }}$ & $30.04^{\text {ns }}$ & $29.06^{\text {ns }}$ & 4.73 \\
\hline \multicolumn{7}{|c|}{$\begin{array}{l}\text { S... Means with different superscripts in the same row differ significantly }(p<0.05) \text { different, } n s=\text { non-significant } \\
\text { SEM - Standard Error of Mean } \\
\text { AMLM - African mistletoe leaf meal }\end{array}$} \\
\hline \multicolumn{7}{|c|}{$\begin{array}{l}\text { Table } 6 \text {. } \\
\text { Organ weight of broiler chickens fed with graded levels of mistletoe leaf meal }\end{array}$} \\
\hline Parameters (g) & $\begin{array}{c}\text { T}_{1} \text {-positive } \\
\text { control } \\
\text { (0\% AMLM, } \\
0.05 \% \\
\text { antibiotics) }\end{array}$ & $\begin{array}{l}\mathbf{T}_{2} \\
(2.5 \% \text { AMLM, } \\
0 \% \text { antibiotics })\end{array}$ & $\begin{array}{l}\mathbf{T}_{3} \\
\text { (5\% AMLM, } 0 \% \\
\text { antibiotics) }\end{array}$ & $\begin{array}{c}\mathbf{T}_{4} \\
(7.5 \% \text { AMLM, } \\
0 \% \text { antibiotics })\end{array}$ & $\begin{array}{c}\mathbf{T}_{5} \text {-negative } \\
\text { control } \\
(0 \% \text { AMLM, } \\
0 \% \text { antibiotics })\end{array}$ & SEM \\
\hline Heart & $4.16^{b}$ & $4.78^{\mathrm{ab}}$ & $5.66^{\mathrm{ab}}$ & $4.82^{\mathrm{ab}}$ & $7.86^{\mathrm{a}}$ & 0.50 \\
\hline Liver & $34.68^{\mathrm{a}}$ & $25.98^{\mathrm{b}}$ & $29.18^{a b}$ & $29.32^{a b}$ & $29.08^{\mathrm{ab}}$ & 1.11 \\
\hline Empt & $26.28^{\mathrm{ab}}$ & $21.52^{\mathrm{b}}$ & $29.22^{\mathrm{a}}$ & $26.96^{\mathrm{ab}}$ & $25.04^{\mathrm{ab}}$ & 0.50 \\
\hline Whole gizzard & $43.20^{\text {ns }}$ & $35.52^{\text {ns }}$ & $42.82^{\text {ns }}$ & $39.14^{\text {ns }}$ & $39.44^{\text {ns }}$ & 1.13 \\
\hline Spleen & $1.00^{\mathrm{ab}}$ & $0.90^{\mathrm{b}}$ & $0.68^{\mathrm{b}}$ & $1.50^{\mathrm{a}}$ & $0.76^{\mathrm{b}}$ & 0.98 \\
\hline Lungs & $80.30^{\mathrm{b}}$ & $92.36^{\mathrm{ab}}$ & $87.10^{\mathrm{ab}}$ & $84.64^{\mathrm{ab}}$ & $100.44^{\mathrm{a}}$ & 2.54 \\
\hline Abdominal fat & $5.64^{\mathrm{a}}$ & $2.34^{\mathrm{b}}$ & $0.80^{\mathrm{C}}$ & $5.24^{\mathrm{a}}$ & $0.90^{\mathrm{c}}$ & 0.55 \\
\hline
\end{tabular}

$a, b, \ldots$ Means with different superscripts in the same row differ significantly $(p<0.05)$ different, $n s=$ non-significant. SEM - Standard Error of Mean

AMLM - African mistletoe leaf meal

Table 7.

Serum profile of broiler chickens fed with graded levels of mistletoe leaf meal

\begin{tabular}{|c|c|c|c|c|c|c|}
\hline Parameters (g) & $\begin{array}{c}\text { T}_{1} \text {-positive } \\
\text { control } \\
\text { (0\% AMLM, } \\
0.05 \% \\
\text { antibiotics) }\end{array}$ & $\begin{array}{c}\mathbf{T}_{2} \\
\text { (2.5\% AMLM, } \\
0 \% \\
\text { antibiotics) }\end{array}$ & $\begin{array}{c}\mathbf{T}_{3} \\
\text { (5\% AMLM, } \\
0 \% \\
\text { antibiotics) }\end{array}$ & $\begin{array}{c}\mathbf{T}_{4} \\
\text { (7.5\% AMLM, } \\
0 \% \\
\text { antibiotics) }\end{array}$ & $\begin{array}{c}\mathbf{T}_{5} \text {-negative } \\
\text { control } \\
\text { (0\% AMLM, } \\
0 \% \\
\text { antibiotics) }\end{array}$ & SEM \\
\hline AST (IU/I) & $197.16^{\text {ns }}$ & $213.83^{\text {ns }}$ & $191.24^{\text {ns }}$ & $192.97^{\text {ns }}$ & $198.44^{\text {ns }}$ & 285.86 \\
\hline $\mathrm{ALT}(\mathrm{IU} / \mathrm{I})$ & $3.75^{\mathrm{d}}$ & $4.87^{\mathrm{c}}$ & $8.08^{\mathrm{a}}$ & $6.07^{\mathrm{b}}$ & $8.30^{\mathrm{a}}$ & 0.56 \\
\hline $\mathrm{TP}(\mathrm{g} / \mathrm{dl})$ & $3.75^{\mathrm{b}}$ & $4.85^{\mathrm{a}}$ & $4.38^{\mathrm{ab}}$ & $4.19^{\mathrm{ab}}$ & $4.74^{\mathrm{a}}$ & 0.29 \\
\hline Globulin (g/dl) & $0.76^{\mathrm{ns}}$ & $1.04^{\mathrm{ns}}$ & $1.00^{\mathrm{ns}}$ & $0.75^{\mathrm{ns}}$ & $1.18^{\mathrm{ns}}$ & 0.28 \\
\hline Creatinine $(\mathrm{mg} / \mathrm{dl})$ & $0.28^{\mathrm{ns}}$ & $0.44^{\mathrm{ns}}$ & $0.33^{\text {ns }}$ & $0.39^{\text {ns }}$ & $0.45^{\mathrm{ns}}$ & 0.03 \\
\hline Urea $(\mathrm{mg} / \mathrm{dl})$ & $6.30^{c}$ & $7.75^{\mathrm{b}}$ & $9.83^{\mathrm{a}}$ & $10.11^{\mathrm{a}}$ & $10.24^{a}$ & 0.30 \\
\hline Glucose $(\mathrm{mg} / \mathrm{dl})$ & $174.32^{\mathrm{a}}$ & $184.51^{\mathrm{b}}$ & $192.22^{\mathrm{b}}$ & $198.15^{\mathrm{b}}$ & $250.00^{\mathrm{b}}$ & 795.77 \\
\hline
\end{tabular}

Meanwhile, birds on AMLM-supplemented diets obtained significantly $(p<0.05)$ higher values of alanine aminotransferase than those on negative control diet (3.75 
IU/I). Urea and glucose contents followed a similar pattern. Traditional herbal practice in many parts of the world involves prescribing combinations of herbs with a wide range of actions that concurrently cover several treatment strategies. Rather than focusing on a specific disease pathology, Herbal practitioners treat holistically with individualized herbal formulae (Williamson, 2001). Combinations provide multiple active constituents working together which may produce additive, or synergistic interacttions.

The result of the proximate composition of the test diet showed that the crude protein, metabolizable energy, and ether extract are adequate. Even though, there was variation in the analysed crude protein composition, this did not affect the performance of the birds. The reason would perhaps be due to the fact that all the diets had crude protein that was well above the least recommendation. In this study, feed intake became not significant as the experiment progressed. Also, Mottaghitalab (2000) earlier observed no differrences in body weight gain of broiler chickens given diets supplemented with different natural feed additives as alternatives to antibiotic growth promoters, which is similar to the findings of the present study, although Guo et al. (2004). reported a significant positive effect on broiler body weight gain exposed to herbs and herbal products. Also, Ocak et al. (2008) and Sarker et al. (2010b) reported no significant difference for body weight gain and feed intake. The variations in the results could be explained by the type and dosage of herbs and herbal products used. Plant extracts contain different molecules that have intrinsic bioactivities affecting animal physiology and metabolism. Some of these compounds have been reported to improve animal performance due to their stimulating effect on salivation and pancreatic enzyme secretions or by having a direct bactericidal effect on gut microflora (Hardy, 2002). Previous studies disagree on carcass characteristics of ani-

mals. Hassan et al. (2004) reported an increase in dressing and liver percentages for broiler chicks fed the supplemented herbal feed additives while Sarker et al. (2010a) reported that herbal plants had no influence on organ weight. The AMLM did not influence most of carcass parts and such results are not strange since it did not influence body weight gain of the experimental animals.

The non-influence of AMLM on creatinine content of the experimental animals is in harmony with the findings of Hossain et al. (2012) who earlier reported that water plantain, mistletoe and antibiotics had no influence on the creatinine content of birds. The observed ALT content was higher for AMLM-supplemented diets but fell within the range reported by Mitruka and Rawnsley (1977). Elevated serum activities could be an indication of heart, kidney and or liver damage owing to cellular destructions caused by toxins (Ewuola and Egbunike, 2008). More studies may be required to ascertain the hematological, immunological, and antimicrobial activities of these plants.

\section{CONCLUSIONS}

It is concluded from the results of this study that AMLM did not influence body weight gain, feed intake and some parts of the carcass characteristics of the reported experimental animals. The AMLM did not seem to pose a threat on biochemical profile of the experimental animals. However, further studies may be required to ascertain the effects of AMLM on biochemical profile of animals, antibacterial properties and effects on immune response of animals.

\section{REFERENCES}

1. EFSA BIOHAZ Panel (EFSA Panel on Biological Hazards) (2013). Scientific Opinion on the public health hazards to be covered by inspection of meat (bovine animals). EFSA Journal, 11 (6), 3266, $261 \mathrm{pp}$. (doi:10.2903/j.efsa.2013.3266).

2. Akinmutimi, A.H. (2006). Nutritive value of raw and processed jack fruit seeds (Artocarpus heterophyllus): Chemical analysis. Agricultural Journal, 1, 266-271.

3. AOAC (2000). Official Methods of Analysis, 17th Ed., AOAC International, Arlington, VA.

4. Cross, D.E., McDevtt R.M., Hilman K., Acamovic T. (2007). The effect of herbs and their associated essential oils on performance, dietary digestibility and gut micro flora in chickens from 7-28 days of age. Brititsh Poultry Science 48, 496-506. 
5. Duncan, D.B. (1995). Multiple range and multiple $\mathrm{F}$ tests. Biometrics, 11, 1-42.

6. Egbenwade, O.O., Olorede, B.R. (2003). Substitution of groundnut cake with mistletoe (Loranthus bengwensis) leaf meal in broiler meal. $8^{\text {th }}$ Annual Conference of the Animal Science Association of Nigeria (ASAN), Nigeria, Proseedings, pp. 1-3.

7. Ewuola, E.O., Egbunike, G.N. (2008). Haematological and serum biochemical response of growing rabbit bucks fed dietary fumonisin $\mathrm{B}_{1}$. African Journal of Biotechnology, 7, 4304-4309.

8. Guo, F.C., Williams, B.A., Kwakkel, R.P., Li, H.S., Li, X.P., Luo, J.Y., Li, W.K., Verstegen, M.W. (2004). Effects of mushroom and herb polysaccharides, as alternatives for an antibiotic, on the cecal microbial ecosystem in broiler chickens. Poultry Science, 83,175-182.

9. Hardy, B. (2002). The issue of antibiotic use in the livestock industry: What have we learned? Animal Biotechology, 13 (1), 129-147

10. Hassan, I.I., Askar, A.A., El-Shourbagy, G.A. (2004). Influence of some medicinal plants on performance; physiological and meat quality traits of broiler chicks. Egyptian Poultry Science, 24, 247-266.

11. Ko, S.Y., Bae, I.H., Yee, S.T., Lee, S.S., Uuganbayar, D., Oh, J.I., Yang, C.J. (2008). Comparison of the effect of green tea by-product and green tea probiotics on the growth performance, meat quality, and immune response of finishing pigs. Asian-Australasian Journal of Animal Science, 21, 1486-1494.

12. Lee, S.D., Kim, H.Y., Song, Y.M., Jung, H.J., Ji, S.Y., Jang, H.D., Ryu, J.W., Park, J.C., Moon, H.K., Kim, I.C. (2009). The effect of Eucommia ulmoides leaf supplementation on the growth performance, blood and meat quality para-meters in growing and finishing pigs. Animal Science Journal, 80, 41-45.

13. Manzanilla, E.G., Perez, J.F., Martin, M., Kamel, C., Baucells, F., Gasa J., (2004). Effect of plant extracts and formic acid on the intestinal equilibrium of early-weaned pigs. Journal of Animal Science, 82, 3210-3218.

14. Hossain, Md. E., Kim, G.M., Sun, S.S., Firman, J.D., Yang, C.J. (2012). Evaluation of water plantain (Alisma canaliculatum A. Br. et Bouche) and mistletoe (Viscum album L.) effects on broiler growth performance, meat composition and serum biochemical parameters. Journal of Medicinal Plants Research, 6 (11), 2160-2169.

15. Mitruka, B.M., Rawnsley, H.M. (1977). Clinical biochemical and haematological reference value in normal experimental animals. Masson Publication, New York, USA., pp. 21-64.

16. Mottaghitalab, M. (2000). Beneficial effects of garlic (Allium sativum) as a growth promoter for broilers and their economic performance. XXI World's Poultry Congress, Montreal, Canada, Proceedings, pp. 18-20.

17. Murthy, K.S., Dutta, K.S., Tajane, K.R., Ravikala, K., Gajbhiye, P.U. (2006). Groundnut haulms alternate roughage for lactating cows. Indian Journal of Animal Nutrition, 23 (2), 110112.

18. NRC (1994). Nutrient Requirements of Poultry, 9th Ed. National Academy Press, Washington, D.C.

19. Ocak, N., Erener, G., Burak, A.K.F., Sung, M., Altop, A., Ozmen, A. (2008). Performance of broilers fed diets supplemented with dry peppermint (Mentha piperita L.) or thyme (Thymus vulgaris L.) leaves as growth promoter source. Czech Journal of Animal Science, 53, 169-175.

20. Ologhobo, A.D., Akangbe, E., Adejumo I.O., Ere, R., Agboola, B. (2017). Haematological and histological evaluation of African mistletoe (Viscum album) leaf meal as feed additive for broilers. Annual Research and Review in Biology, 15 (3), 1-7.

21. Sarker, M.S.K., Kim, G.M., Ji, H., Park, M.R.E., Yang, C.J. (2010a). Effect of different medicinal plants with probiotics on growth performance and meat composition and lipid oxidation in Ross broilers. Annual Congress of Korean Society of Animal Sciences and Technology, South Korea, Proceedings, p. 210.

22. Sarker, M.S.K., Park, S.R., Kim, G.M., Yang, C.J. (2010b). Hamcho (Salicornia herbacea) with probiotics as alternative to antibiotic for broiler production. Journal of Medicinal Plant Research, 4, 415-420.

23. Wenk, C. (2003). Herbs and botanicals as feed additives in monogastric animals. Asian-Australasian Journal of Animal Science, 16, 282-289.

24. Williamson, E.M. (2001). Synergy and other interactions in phytomedicines. Phytomedicine, 8 (5), 401- 409. 


\section{УТИЦАЈ ХРАНЕ НА БАЗИ ИМЕЛЕ (Viscum album) НА ПЕРФОРМАНСЕ РАСТА, КВАЛИТЕТ ТРУПА И БИОХЕМИЈСКИ ПРОФИЛ ПИЛИЋА БРОЈЛЕР}

Anthony D. Ologhobo ${ }^{1}$, Isaac Oluseun Adejumo*2 ${ }^{2}$ Temitope Owoeye ${ }^{1}$, Akangbe Esther $^{1}$

${ }^{1}$ Универзитет Ибадан, Департман за науку о животињама, Јединица за биохемију животиња и испитивање хране, Ибадан, Нигерија

${ }^{2}$ Федерални универзитет, Департман за науку о животињама, исхрану животиња, биотехнологија и безбедност хране, Гашуа, Нигерија

Сажетак: Истраживање алтернатива за антибиотике је довела до открића пребиотика а потрага за алтернативама је и даље актуелна. У овом раду, испитује се пребиотички потенцијал хране за животиње са додатком лишћа имеле (Viscum album) са циљем проналажења пребиотика као замене за антибиотике, а који би могли да се користе за оптимизацију перформанси животиња, побољшање квалитета трупа и здравственог профила крви, као индикатора системског стања животиње. Формулисано је пет експерименталних хранива у којима је додата имела (АМЛМ) у различитим концентрацијама ( $0 \%$ са $0,5 \%$ антибиотика (позитивна контрола); 2,5\%; 5,0\%; 7,5\% без антибиотика (негативна контрола)). Маса тела пилића се није значајно мењала у току третмана. Маса живих пилића, пилића после клања, крила, батака, карабатака, груди и главе се нису значајно мењали у току третмана. Вредности аспартат аминотрансферазе, глобулина и креатинина се такође нису значајно мењали у току третмана. Код пилића који су храњени храном са додатком АМЛМ показан је значајан саджај ( $<0.05)$ аланин трансфреразе у односу на негативну контролу (3.75 IU/I). Садржаји урее и глукозе су следиле сличан образац. АМЛМ може да се користи као алтернативни антибиотик у производњи бројлера мада су потребна даља, опсежнија истраживања за потврду његовог потенцијала.

Кључне речи: антибиотици, бројлери, исхрана, Viscum album

Received: 23 May 2017

Accepted: 26 October 2017 